Buana Sains Vol 18 No 1 : 1-10, 2018

\title{
KEMAMPUAN Azetobacter sp. DALAM MENINGKATKAN EFISIENSI PEMUPUKAN UREA PADA TANAMAN JAGUNG \\ (Zea mays L.)
}

\author{
Nur Winda Rachmadhani, Didik Hariyono, Mudji Santosa \\ Program Pascasarjana, Fakultas Pertanian, Universitas Brawijaya
}

\begin{abstract}
Azotobacter sp. is a non-symbiotic bacteria that has the ability to mobilize nitrogen from a form that is not available in a form that is available for plants. Inoculation of Azotobacter sp. into the planting medium can be used as a supplier of nitrogen required by the plant. Utilization of Azotobacter sp. as biofertilizer has the ability to minimize the use of chemical fertilizers, improve the soil fertility and increase the microbial activity in the rhizosphere of plants. Inoculation of Azotobacter sp. into the planting medium is one alternative to improve the efficiency of urea fertilizer in the maize cultivation. The result of this research showed that the application of Azotobacter sp. with the dose of $10 \mathrm{ml} \mathrm{l}^{-1}$ and $20 \mathrm{ml} \mathrm{l}^{-1}$ on the urea fertilization with the dose of 150 $\mathrm{kg} \mathrm{ha}{ }^{-1}$ were able to increase the growth of maize, so that maize has growth that was not significantly different with the maize that got urea with the dose of $225 \mathrm{~kg} \mathrm{ha}^{-1}$ and 300 $\mathrm{kg} \mathrm{ha}{ }^{-1}$. Inoculation of Azotobacter sp. in the planting media, either with the dose of 10 $\mathrm{ml} \mathrm{l}{ }^{-1}$ or $20 \mathrm{ml} \mathrm{l}^{-1}$ were able to increase the maize yield when compared to the treatment without Azotobacter sp. Inoculation of Azotobacter sp. into the planting medium was able to increase the maize yield. However, increasing the dose of Azotobacter sp. more than $10 \mathrm{ml} \mathrm{l}^{-1}$ did not affect to increase the maize yield. Maize yield reached the optimum value when the dose of urea supplied was153.50 $\mathrm{kg} \mathrm{ha}^{-1}$.
\end{abstract}

Keywords: Aqotobacter sp.; urea; efficiency; growth; yield

\section{Pendahuluan}

Di Indonesia, jagung (Zea mays L.) merupakan komoditas strategis dan bernilai ekonomis hal ini dikarenakan kedudukannya sebagai sumber bahan makanan, bahan baku industri dan pakan ternak. Tingginya kebutuhan jagung dalam negeri menyebabkan nilai impor jagung di Indonesia cukup tinggi. Pada periode 2010-2013, nilai impor jagung di Indonesia mencapai 10,24 juta ton (Kementerian Pertanian, 2014). Belum terpenuhinya kebutuhan jagung di dalam negeri ini disebabkan oleh beberapa hal, salah satunya ialah pelaksanaan teknis pemupukan yang kurang tepat.

Salah satu unsur hara utama yang dibutuhkan oleh tanaman jagung selama siklus hidupnya ialah nitrogen. Tanaman jagung membutuhkan unsur nitrogen sepanjang hidupnya, yaitu selama masa pertumbuhan sampai pematangan biji. Apabila ketersediaan hara dalam tanah tidak mencukupi kebutuhan hara tanaman jagung, maka dapat mempengaruhi pertumbuhan dan hasil tanaman tersebut. Hal ini akan terlihat 
N.W. Rachmadhani, D. Hariyono, M. Santosa/ Buana Sains Vol 18 No 1 : 1-10

jelas pada komponen pertumbuhan dan hasil tanaman yang mengalami stagnasi, gagal tumbuh, atau berkembang secara abnormal (Muyasir, 2013).

Sumber hara nitrogen yang seringkali dimanfaatkan oleh petani pada budidaya tanaman jagung biasanya bersumber dari pupuk anorganik, seperti halnya urea. Kegiatan usaha tani yang intensif telah mendorong pemakaian pupuk anorganik yang terus meningkat. Meskipun demikian, hasil panen yang didapatkan tidak sebanding dengan input pemupukan yang telah diberikan. Rendahnya efisiensi pemupukan urea tersebut dikarenakan unsur nitrogen yang terkandung di dalam pupuk urea memiiki sifat mobile dan mudah berubah bentuk menjadi gas, sehingga unsur nitrogen yang terkandung mudah hilang melalui proses prosese penguapan maupun pencucian. Dari total pupuk urea yang diaplikasikan, tanaman hanya mampu menyerap sebesar 30-40\%, dan bahkan efisiensinya dapat lebih rendah lagi pada beberapa kasus (Jamilah dan Safridar, 2012; Danapriatna, 2010). Hal ini menyebabkan serapan $\mathrm{N}$ tanaman menjadi rendah karena ketersediaan unsur nitrogen di dalam tanah juga rendah.

Salah satu alternatif yang dapat dilakukan guna memenuhi kebutuhan unsur hara tanaman jagung ialah dengan memanfaatkan biofertilizer (pupuk hayati). Salah satu pupuk hayati yang menguntungkan bagi pertumbuhan dan produksi tanaman ialah Azotobacter sp. Bakteri tersebut merupakan bakteri non simbiotik yang memiliki kemampuan dalam menambat nitrogen dari atmosfer, di mana mampu menyumbang $\mathrm{N}$ pada tanah sebanyak $20 \mathrm{~kg} \mathrm{ha}^{-1} \mathrm{th}^{-1}$ (Baral dan Adhikari, 2013). Oleh karena itu, dengan memanfaatkan Azotobacter sp., diharapkan kebutuhan unsur hara nitrogen pada tanaman jagung dapat terpenuhi, dan penggunaan pupuk urea dapat lebih dihemat. Hindersah, Sulaksana dan Herdiyantoro (2014) juga menyatakan bahwa inokulasi Azotobacter sp. pada media tanam mampu meningkatkan efisiensi pemupukan anorganik sampai dengan $30 \%$ pada ekosistem lahan kering.

\section{Metode Penelitian}

Penelitian dilaksakan di lahan petani yang terletak di Desa Donowarih, Kecamatan Karangploso, Kabupaen Malang, dengan ketinggian tempat \pm 600 mdpl dengan jenis tanah Inceptisol. Penelitian ini dilaksanakan pada bulan Februari sampai dengan Juni 2016. Alat yang digunakan dalam penelitian ini meliputi: hand sprayer, timbangan analitik, oven dan kamera. Bahan yang digunakan dalam penelitian ini meliputi: benih jagung varietas DK 771, inokulan Azotobacter sp. dengan konsentrasi $10^{8} \mathrm{cfu}$ $\mathrm{ml}^{-1}$, pupuk urea, pupuk SP-36, pupuk $\mathrm{KCl}$, kompos kotoran kambing dan polibag.

Penelitian ini dilaksanakan dengan menggunakan Rancangan Acak Kelompok Faktorial (RAKF). Perlakuan yang diberikan terdiri dari dua faktor. Faktor pertama ialah dosis inokulan Azotobacter sp. yang terdiri dari 3 taraf, yaitu: dosis Azotobacter sp. $0 \mathrm{ml} \mathrm{l}^{-1}\left(\mathrm{~A}_{0}\right)$, dosis Azotobacter sp. $10 \mathrm{ml} \mathrm{l}^{-1}\left(\mathrm{~A}_{10}\right)$ dan dosis Azotobacter sp. $20 \mathrm{ml} \mathrm{l}^{-1}\left(\mathrm{~A}_{20}\right)$. Faktor kedua ialah pemupukan urea yang terdiri dari 5 taraf, yaitu: pemupukan urea $0 \mathrm{~kg}$ $\mathrm{ha}^{-1}\left(\mathrm{U}_{0}\right)$, pemupukan urea $75 \mathrm{~kg} \mathrm{ha}{ }^{-1}$ $\left(\mathrm{U}_{75}\right)$, pemupukan urea $150 \mathrm{~kg} \mathrm{ha}^{-1}\left(\mathrm{U}_{150}\right)$, pemupukan urea $225 \mathrm{~kg} \mathrm{ha}^{-1}\left(\mathrm{U}_{225}\right)$ dan pemupukan urea $300 \mathrm{~kg} \mathrm{ha}^{-1}\left(\mathrm{U}_{300}\right)$. Total perlakuan dalam penelitian ini adalah 15 perlakuan, di mana setiap perlakuan diulang sebanyak 3 kali, sehingga terdapat 45 satuan percobaan.

Pengamatan pada pertumbuhan dilakukan secara destruktif dan non 
N.W. Rachmadhani, D. Hariyono, M. Santosa/ Buana Sains Vol 18 No 1 : 1-10

destruktif. Pengamatan terhadap peubah jumlah daun, luas daun dan indeks luas daun dilakukan secara non destruktif pada saat tanaman berumur 21 hst, 31 hst, 41 hst, 51 hst, 61 hst, 71 hst dan 81 hst. Pengamatan terhadap peubah bobot segar dan bobot kering tanaman dilakukan secara destruktif pada saat tanaman mencapai fase vegetatif puncak (60 hst). Pengamatan panen dilakukan pada saat tanaman menujukkan kriteria masak fisiologis (120 hst). Peubah yang diamati pada pengamatan hasil meliputi: jumlah biji per tanaman, bobot kering biji per tanaman, bobot kering biji per plot dan bobot kering biji per hektar. Data yang diperoleh dari hasil pengamatan dianalisis dengan menggunakan analisis ragam (uji F) pada taraf $5 \%$, dan apabila berbeda nyata maka dilanjutkan dengan uji BNT pada taraf $5 \%$ untuk mengetahui perbedaan di antara perlakuan.

\section{Hasil dan Pembahasan}

\section{Pertumbuhan Tanaman}

Hasil analisis ragam menunjukkan bahwa terjadi interaksi yang nyata antara dosis Azotobacter sp. dan pupuk urea pada beberapa parameter pertumbuhan tanaman, antara lain: jumlah daun (Tabel 1), luas daun (Tabel 3) dan indeks luas daun (Tabel 5), yang terjadi pada umur 61 hst. Berdasarkan hasil pengamatan, ketiganya menunjukkan kecendrungan yang sama, dimana pemberian Azotobacter sp. dengan dosis $10 \mathrm{ml} \mathrm{l}^{-1}$ dan $20 \mathrm{ml} \mathrm{l}^{-1}$ pada pemupukan urea dengan taraf 150 $\mathrm{kg} \mathrm{ha}{ }^{-1}$ mampu menghasilkan rata-rata jumlah daun, luas daun dan indeks luas daun yang lebih tinggi apabila dibandingkan dengan perlakuan pemberian Azotobacter sp. dengan dosis 0 $\mathrm{ml} \mathrm{l}^{-1}$ pada pemupukan urea dengan taraf yang sama. Pemberian Azotobacter sp. dengan dosis $10 \mathrm{ml} \mathrm{l}^{-1}$ dan $20 \mathrm{ml} \mathrm{l}^{-1}$ pada pemupukan urea dengan taraf $150 \mathrm{~kg} \mathrm{ha}^{-1}$ terbukti telah mampu meningkatkan pertumbuhan tanaman jagung, sehingga tanaman jagung tersebut memiliki ratarata jumlah daun, luas daun dan indeks luas daun yang tidak berbeda nyata dengan tanaman jagung yang diberi pupuk urea dengan taraf yang lebih tinggi, yaitu $225 \mathrm{~kg} \mathrm{ha}^{-1}$ dan $300 \mathrm{~kg} \mathrm{ha}^{-1}$. $\mathrm{Hal}$ ini dapat terjadi dikarenakan pemberian Aqotobacter sp. pada media tanam mampu menyediakan nitrogen tambahan bagi tanaman jagung, mengingat Azotobacter sp. memiliki kemampuan dalam memfiksasi nitrogen bebas dari atmosfer (Rao, 2010 dan Syam'un, Kaimuddin dan Dachlan, 2012).

Tabel 1.Interaksi antara Dosis Aqotobacter sp. dan Pupuk Urea terhadap Rata Rata Jumlah Daun Tanaman Jagung pada Umur 61 hst

\begin{tabular}{|c|c|c|c|c|c|}
\hline \multirow{3}{*}{ Azotobacter sp. } & \multicolumn{5}{|c|}{ Jumlah Daun (Helai) pada Umur 61 hst } \\
\hline & \multicolumn{5}{|c|}{ Urea } \\
\hline & $0 \mathrm{~kg} \mathrm{ha}^{-1}$ & $75 \mathrm{~kg} \mathrm{ha}^{-1}$ & $150 \mathrm{~kg} \mathrm{ha}^{-1}$ & $225 \mathrm{~kg} \mathrm{ha}^{-1}$ & $300 \mathrm{~kg} \mathrm{ha}^{-1}$ \\
\hline $0 \mathrm{ml} \mathrm{l}^{-1}$ & $8,89 \mathrm{ab}$ & $9,33 \mathrm{abc}$ & $9,33 \mathrm{abc}$ & $11,33 \mathrm{de}$ & 11,89 e \\
\hline $10 \mathrm{ml} \mathrm{l}^{-1}$ & $8,34 \mathrm{a}$ & 9,89 bc & $12,22 \mathrm{e}$ & $12,22 \mathrm{e}$ & $11,56 \mathrm{e}$ \\
\hline $20 \mathrm{ml} \mathrm{l}^{-1}$ & $9,22 \mathrm{abc}$ & $10,22 \mathrm{~cd}$ & $12,00 \mathrm{e}$ & $11,55 \mathrm{e}$ & $12,56 \mathrm{e}$ \\
\hline BNT $5 \%$ & & & 1,28 & & \\
\hline
\end{tabular}

Keterangan: Bilangan yang didampingi oleh huruf yang sama berarti tidak berbeda nyata berdasarkan uji BNT pada taraf 5\%; hst $=$ hari setelah tanam; BNT $=$ Beda Nyata Terkecil; KK $=$ Koefisien Keragaman 
N.W. Rachmadhani, D. Hariyono, M. Santosa/ Buana Sains Vol 18 No 1 : 1-10

Tabel 2.Rata-Rata Jumlah Daun Tanaman Jagung Hasil Perlakuan Dosis Azotobacter sp. dan Pupuk Urea mulai Umur 21 hst sampai dengan 81 hst

\begin{tabular}{|c|c|c|c|c|c|c|}
\hline \multirow{2}{*}{ Perlakuan } & \multicolumn{6}{|c|}{ Jumlah Daun (Helai) pada Umur } \\
\hline & $21 \mathrm{hst}$ & 31 hst & $41 \mathrm{hst}$ & 51 hst & 71 hst & 81 hst \\
\hline Arotobacter sp. & & & & & & \\
\hline $0 \mathrm{ml} \mathrm{l}^{-1}$ & 5,53 & $6,30 \mathrm{a}$ & $7,44 \mathrm{a}$ & 8,16 & 12,91 & 12,31 \\
\hline $10 \mathrm{ml} \mathrm{l}^{-1}$ & 5,73 & $7,27 \mathrm{~b}$ & $7,62 \mathrm{ab}$ & 8,36 & 12,98 & 12,67 \\
\hline $20 \mathrm{ml} \mathrm{l}^{-1}$ & 5,50 & $7,20 \mathrm{~b}$ & $7,93 \mathrm{~b}$ & 8,36 & 13,09 & 12,58 \\
\hline BNT $5 \%$ & tn & 0,68 & 0,44 & tn & tn & tn \\
\hline Urea & & & & & & \\
\hline $0 \mathrm{~kg} \mathrm{ha}^{-1}$ & 5,17 & $5,61 \mathrm{a}$ & $6,48 \mathrm{a}$ & $7,55 \mathrm{a}$ & $11,19 \mathrm{a}$ & $10,93 \mathrm{a}$ \\
\hline $75 \mathrm{~kg} \mathrm{ha}^{-1}$ & 5,50 & $6,22 \mathrm{a}$ & $7,07 \mathrm{~b}$ & $7,78 \mathrm{ab}$ & $12,78 \mathrm{~b}$ & $12,33 \mathrm{~b}$ \\
\hline $150 \mathrm{~kg} \mathrm{ha}^{-1}$ & 5,61 & $7,22 \mathrm{~b}$ & $7,96 \mathrm{c}$ & $8,41 \mathrm{bc}$ & $13,44 \mathrm{bc}$ & $12,52 \mathrm{bc}$ \\
\hline $225 \mathrm{~kg} \mathrm{ha}^{-1}$ & 5,94 & $7,83 \mathrm{~b}$ & $8,33 \mathrm{c}$ & $8,74 \mathrm{c}$ & $13,74 \mathrm{c}$ & $13,41 \mathrm{c}$ \\
\hline $300 \mathrm{~kg} \mathrm{ha}^{-1}$ & 3,72 & $7,72 \mathrm{~b}$ & $8,48 \mathrm{c}$ & $8,96 \mathrm{c}$ & $13,82 \mathrm{c}$ & $13,41 \mathrm{c}$ \\
\hline BNT $5 \%$ & tn & 0,88 & 0,57 & 0,66 & 0,95 & 0,90 \\
\hline
\end{tabular}

Keterangan: Bilangan yang didampingi oleh huruf yang sama pada kolom yang sama berarti tidak berbeda nyata berdasarkan uji BNT pada taraf 5\%; hst = hari setelah tanam; tn = tidak nyata; BNT = Beda Nyata Terkecil; KK = Koefisien Keragaman

Terjadinya peningkatan jumlah daun dan luas daun tanaman jagung berhubungan erat dengan terjadinya aktivitas pembelahan sel, pembesaran sel dan juga diferensiasi sel. Salah satu faktor yang sangat berpengaruh terhadap aktivitas tersebut adalah ketersediaan unsur nitrogen. Nitrogen merupakan unsur hara utama bagi pertumbuhan tanaman yang berperan sebagai penyusun dari semua protein dan asam nukleat, atau penyusun protoplasma secara keseluruhan (Widiyawati el al., 2014 dan Syam'un et al., 2012). Tanaman yang kebutuhan unsur nitrogennya terpenuhi dengan baik akan memiliki kandungan klorofil daun yang optimal, sehingga tanaman mampu menyerap cahaya dengan jumlah yang optimal, yang selanjutnya laju proses fotosintesis dapat berlangsung secara optimal pula. Fotosintat yang dihasilkan dari proses fotosintesis tersebut akan ditranslokasikan ke bagian organ vegetatif tanaman, dan pada akhirnya akan meningkatkan jumlah daun dan luas daun tanaman (Sitompul dan Guritno, 1995).

Tabel 3. Interaksi antara Dosis Aqotobacter sp. dan Pupuk Urea terhadap Rata-Rata Luas Daun Tanaman Jagung pada Umur 61 hst

\begin{tabular}{|c|c|c|c|c|c|}
\hline \multirow{3}{*}{ Azotobacter sp } & \multicolumn{5}{|c|}{ Luas Daun $\left(\mathrm{cm}^{2}\right)$ pada Umur 61 hst } \\
\hline & \multicolumn{5}{|c|}{ Urea } \\
\hline & $0 \mathrm{~kg} \mathrm{ha}^{-1}$ & $75 \mathrm{~kg} \mathrm{ha}^{-1}$ & $150 \mathrm{~kg} \mathrm{ha}^{-1}$ & $225 \mathrm{~kg} \mathrm{ha}^{-1}$ & $300 \mathrm{~kg} \mathrm{ha}^{-1}$ \\
\hline $0 \mathrm{ml} \mathrm{l}^{-1}$ & $2991,51 \mathrm{abc}$ & 3448,54 abc & $3478,84 \mathrm{abc}$ & $5116,03 \mathrm{e}$ & 5377,10 e \\
\hline $10 \mathrm{ml} \mathrm{l}^{-1}$ & 2718,47 a & 3847,38 bc & $5254,66 \mathrm{e}$ & 5896,98 e & $4924,22 \mathrm{de}$ \\
\hline $20 \mathrm{ml} \mathrm{l}^{-1}$ & $2939,88 \mathrm{ab}$ & $3953,24 \mathrm{~cd}$ & 5581,88 e & 5312,08 e & 5802,83 e \\
\hline BNT 5\% & \multicolumn{5}{|c|}{988,91} \\
\hline
\end{tabular}

Keterangan: Bilangan yang didampingi oleh huruf yang sama berarti tidak berbeda nyata berdasarkan uji BNT pada taraf 5\%; hst $=$ hari setelah tanam; BNT $=$ Beda Nyata Terkecil; KK $=$ Koefisien Keragaman 
N.W. Rachmadhani, D. Hariyono, M. Santosa/ Buana Sains Vol 18 No 1 : 1-10

Tabel 4.Rata-Rata Luas Daun Tanaman Jagung Hasil Perlakuan Dosis Azotobacter sp. dan Pupuk Urea mulai Umur 21 hst sampai dengan 81 hst

\begin{tabular}{|c|c|c|c|c|c|c|}
\hline \multirow{2}{*}{ Perlakuan } & \multicolumn{6}{|c|}{ Luas Daun $\left(\mathrm{cm}^{2}\right)$ pada Umur } \\
\hline & $21 \mathrm{hst}$ & 31 hst & 41 hst & $51 \mathrm{hst}$ & 71 hst & 81 hst \\
\hline \multicolumn{7}{|l|}{ Azotobacter sp. } \\
\hline $0 \mathrm{ml} \mathrm{l}^{-1}$ & 165,36 & $661,21 \mathrm{a}$ & $1402,49 \mathrm{a}$ & $2844,11 \mathrm{a}$ & 4976,32 & 4340,80 \\
\hline $10 \mathrm{ml} \mathrm{l}^{-1}$ & 192,00 & $753,44 \mathrm{ab}$ & $1722,58 \mathrm{~b}$ & $3160,54 \mathrm{ab}$ & 5123,85 & 4745,88 \\
\hline $20 \mathrm{ml} \mathrm{l}^{-1}$ & 183,70 & 891,52 b & $1895,24 \mathrm{~b}$ & 3329,37 b & 5346,90 & 4536,11 \\
\hline BNT $5 \%$ & tn & 154,50 & 281,27 & 349,07 & tn & tn \\
\hline \multicolumn{7}{|l|}{ Urea } \\
\hline $0 \mathrm{~kg} \mathrm{ha}^{-1}$ & $106,80 \mathrm{a}$ & 397,33 a & $801,57 \mathrm{a}$ & $1902,59 \mathrm{a}$ & $3679,96 \mathrm{a}$ & $3306,52 \mathrm{a}$ \\
\hline $75 \mathrm{~kg} \mathrm{ha}^{-1}$ & $156,46 \mathrm{ab}$ & $563,93 \mathrm{a}$ & $1175,17 \mathrm{~b}$ & $2562,48 \mathrm{~b}$ & $4734,74 \mathrm{~b}$ & $4110,02 \mathrm{~b}$ \\
\hline $150 \mathrm{~kg} \mathrm{ha}^{-1}$ & $214,75 \mathrm{bc}$ & 814,68 b & $1752,79 \mathrm{c}$ & $3309,39 \mathrm{c}$ & $5265,45 \mathrm{bc}$ & $4817,79 \mathrm{c}$ \\
\hline $225 \mathrm{~kg} \mathrm{ha}^{-1}$ & $237,53 \mathrm{c}$ & $1122,21 \mathrm{c}$ & $2404,45 \mathrm{~d}$ & $3998,26 \mathrm{~d}$ & $6167,27 \mathrm{~d}$ & $5299,87 \mathrm{c}$ \\
\hline $300 \mathrm{~kg} \mathrm{ha}^{-1}$ & $186,25 \mathrm{bc}$ & 945,48 bc & $2233,21 \mathrm{~d}$ & $3783,99 \mathrm{~d}$ & $5897,69 \mathrm{~cd}$ & $5170,44 \mathrm{c}$ \\
\hline BNT $5 \%$ & 67,38 & 199,45 & 363,12 & 450,64 & 662,17 & 598,58 \\
\hline
\end{tabular}

Keterangan: Bilangan yang didampingi oleh huruf yang sama pada kolom yang sama berarti tidak berbeda nyata berdasarkan uji BNT pada taraf 5\%; hst = hari setelah tanam; tn = tidak nyata; $\mathrm{BNT}=$ Beda Nyata Terkecil; KK = Koefisien Keragaman

Meningkatnya luas daun tanaman jagung akan berpengaruh terhadap peningkatan nilai indeks luas daunnya. Indeks luas daun merupakan rasio antara luas daun dan luas tanah yang ternaungi (Sitompul dan Guritno, 1995). Oleh karena itu, pada jarak tanam yang sama, semakin tinggi nilai luas daun akan menyebabkan nilai indeks luas daun yang dihasilkan juga meningkat. Hal ini sebagaimana hasil penelitian, di mana tanaman jagung yang diberi pupuk urea dengan taraf $150 \mathrm{~kg} \mathrm{ha}^{-1}$ yang disertai dengan adanya inokulasi Azotobacter sp. dengan dosis $10 \mathrm{ml} \mathrm{l}^{-1}$ dan $20 \mathrm{ml} \mathrm{l}^{-1}$ pada media tanam, serta tanaman jagung yang diberi pupuk urea dengan taraf yang lebih tinggi, yaitu $225 \mathrm{~kg} \mathrm{ha}^{-1}$ dan $300 \mathrm{~kg} \mathrm{ha}^{-1}$, terbukti memiliki rata-rata nilai luas daun (Tabel 3) yang lebih tinggi, yang pada akhirnya akan menghasilkan nilai ratarata indeks luas daun (Tabel 5) yang lebih tinggi pula apabila dibandingkan dengan perlakuan lainnya.

Tabel 5.Interaksi antara Dosis Aqotobacter sp. dan Pupuk Urea terhadap Rata-Rata Indeks Luas Daun Tanaman Jagung pada Umur 61 hst

\begin{tabular}{|c|c|c|c|c|c|}
\hline \multirow{3}{*}{ Arotobacter sp. } & \multicolumn{5}{|c|}{ Indeks Luas Daun pada Umur 61 hst } \\
\hline & & & Urea & & \\
\hline & $0 \mathrm{~kg} \mathrm{ha}^{-1}$ & $75 \mathrm{~kg} \mathrm{ha}^{-1}$ & $150 \mathrm{~kg} \mathrm{ha}^{-1}$ & $225 \mathrm{~kg} \mathrm{ha}^{-1}$ & $300 \mathrm{~kg} \mathrm{ha}^{-1}$ \\
\hline $0 \mathrm{ml} \mathrm{l}^{-1}$ & $1,00 \mathrm{abc}$ & $1,15 \mathrm{abc}$ & $1,16 \mathrm{abc}$ & $1,71 \mathrm{e}$ & $1,79 \mathrm{e}$ \\
\hline $10 \mathrm{ml} \mathrm{l}^{-1}$ & $0,90 \mathrm{a}$ & $1,28 \mathrm{bc}$ & $1,75 \mathrm{e}$ & $1,97 \mathrm{e}$ & $1,64 \mathrm{de}$ \\
\hline $20 \mathrm{ml} \mathrm{l}^{-1}$ & $0,98 \mathrm{ab}$ & $1,32 \mathrm{~cd}$ & $1,86 \mathrm{e}$ & $1,77 \mathrm{e}$ & $1,93 \mathrm{e}$ \\
\hline
\end{tabular}

Keterangan: Bilangan yang didampingi oleh huruf yang sama berarti tidak berbeda nyata berdasarkan uji BNT pada taraf 5\%; hst = hari setelah tanam; BNT = Beda Nyata Terkecil; KK $=$ Koefisien Keragaman 
N.W. Rachmadhani, D. Hariyono, M. Santosa/ Buana Sains Vol 18 No 1 : 1-10

Tabel 6.Rata-Rata Indeks Luas Daun Tanaman Jagung Hasil Perlakuan Dosis Azotobacter sp. dan Pupuk Urea mulai Umur 21 hst sampai dengan 81 hst

\begin{tabular}{|c|c|c|c|c|c|c|}
\hline \multirow{2}{*}{ Perlakuan } & \multicolumn{6}{|c|}{ Indeks Luas Daun pada Umur } \\
\hline & 21 hst & 31 hst & 41 hst & 51 hst & 71 hst & 81 hst \\
\hline \multicolumn{7}{|l|}{ Azotobacter sp. } \\
\hline $0 \mathrm{ml} \mathrm{l}^{-1}$ & 0,06 & $0,22 \mathrm{a}$ & $0,47 \mathrm{a}$ & $0,95 \mathrm{a}$ & 1,66 & 1,45 \\
\hline $10 \mathrm{ml} \mathrm{l}^{-1}$ & 0,06 & $0,25 \mathrm{ab}$ & $0,57 \mathrm{ab}$ & $1,05 \mathrm{ab}$ & 1,71 & 1,58 \\
\hline $20 \mathrm{ml} \mathrm{l}^{-1}$ & 0,06 & $0,30 \mathrm{~b}$ & $0,63 \mathrm{~b}$ & $1,11 \mathrm{~b}$ & 1,78 & 1,51 \\
\hline BNT $5 \%$ & th & 0,05 & 0,10 & 0,12 & tn & th \\
\hline \multicolumn{7}{|l|}{ Urea } \\
\hline $0 \mathrm{~kg} \mathrm{ha}^{-1}$ & $0,04 \mathrm{a}$ & $0,13 \mathrm{a}$ & $0,27 \mathrm{a}$ & $0,63 \mathrm{a}$ & $1,23 \mathrm{a}$ & $1,10 \mathrm{a}$ \\
\hline $75 \mathrm{~kg} \mathrm{ha}^{-1}$ & $0,05 \mathrm{ab}$ & $0,19 \mathrm{a}$ & $0,39 \mathrm{~b}$ & $0,85 \mathrm{~b}$ & $1,58 \mathrm{~b}$ & $1,37 \mathrm{~b}$ \\
\hline $150 \mathrm{~kg} \mathrm{ha}^{-1}$ & $0,07 \mathrm{bc}$ & $0,27 \mathrm{~b}$ & $0,58 \mathrm{c}$ & $1,10 \mathrm{c}$ & $1,76 \mathrm{bc}$ & $1,61 \mathrm{c}$ \\
\hline $225 \mathrm{~kg} \mathrm{ha}^{-1}$ & $0,08 \mathrm{c}$ & $0,37 \mathrm{c}$ & $0,80 \mathrm{~d}$ & $1,33 \mathrm{~d}$ & $2,06 \mathrm{~d}$ & $1,77 \mathrm{c}$ \\
\hline $300 \mathrm{~kg} \mathrm{ha}^{-1}$ & $0,06 \mathrm{bc}$ & $0,32 \mathrm{bc}$ & $0,74 \mathrm{~d}$ & $1,26 \mathrm{~d}$ & $1,97 \mathrm{~cd}$ & $1,72 \mathrm{c}$ \\
\hline BNT $5 \%$ & 0,02 & 0,07 & 0,12 & 0,15 & 0,22 & 0,20 \\
\hline
\end{tabular}

Keterangan: Bilangan yang didampingi oleh huruf yang sama pada kolom yang sama berarti tidak berbeda nyata berdasarkan uji BNT pada taraf 5\%; hst = hari setelah tanam; tn = tidak nyata; BNT = Beda Nyata Terkecil; KK = Koefisien Keragaman.

Dari hasil penelitian ini terdapat kecenderungan bahwa inokulasi Azotobacter sp. pada media tanam dengan dosis $10 \mathrm{ml} \mathrm{l}^{-1}$ dan $20 \mathrm{ml} \mathrm{l}^{-1}$ mampu meningkatkan pertumbuhan tanaman jagung apabila diberikan pada perlakuan pemupukan urea dengan taraf $150 \mathrm{~kg}$ ha 1. Pada pemupukan urea dengan taraf yang tinggi, yaitu $225 \mathrm{~kg} \mathrm{ha}^{-1}$ maupun 300 $\mathrm{kg} \mathrm{ha}{ }^{-1}$, pemberian Arotobacter sp. tidak mampu meningkatkan jumlah daun (Tabel 1), luas daun (Tabel 3) dan indeks luas daun (Tabel 5). Hal ini diduga karena pemupukan nitrogen dalam jumlah besar akan menyebabkan kegiatan rhizobia (Azotobacter sp.) menjadi menurun, sehingga akan menyebabkan inokulasi rhizobia tersebut menjadi kurang efektif (Rosmarkam dan Yuwono, 2002). Pada pemupukan urea dengan taraf yang rendah, yaitu $75 \mathrm{~kg} \mathrm{ha}{ }^{-1}$, maupun tanpa pemupukan urea, pemberian Azotobacter sp. juga tidak mampu meningkatkan jumlah daun, luas daun dan indeks luas daun. Hal ini diduga karena kandungan unsur nitrogen yang tersedia dalam tanah belum mampu mencukupi kebutuhan tanaman. Pada dasarnya, tanaman tetap memerlukan sumber unsur nitrogen lain meskipun pada media tanam diinokulasi dengan Azotobacter sp.

Berdasarkan hasil analisis ragam menunjukkan bahwa tidak terjadi interaksi yang nyata antara dosis Azotobacter sp. dan pupuk urea pada peubah jumlah daun (Tabel (Tabel 2), luas daun (Tabel 4) dan indeks luas daun (Tabel 6) pada saat tanaman jagung berumur 21, 31, 41, 51, 71, dan 81 hst. Meskipun demikian, perlakuan dosis Arotobacter sp. dan pupuk urea masingmasing secara mandiri memberikan pengaruh yang nyata terhadap ketiga peubah tersebut. Berdasarkan hasil pengamatan terdapat kecenderungan bahwa perlakuan inokulasi Azotobacter sp. memberikan pengaruh terhadap peubah luas daun dan indeks luas daun pada umur 31 hst sampai dengan 51 hst, dan memberikan pengaruh terhadap peubah jumlah daun pada umur 31 hst sampai 
N.W. Rachmadhani, D. Hariyono, M. Santosa/ Buana Sains Vol 18 No 1 : 1-10

dengan 41 hst. Secara umum, meningkatnya dosis pemberian Azotobacter sp. akan diikuti dengan meningkatnya jumlah daun, luas daun dan indeks luas daun. Selain kemampuannya dalam memfiksasi nitrogen dari udara bebas, Azotobacter sp. juga memiliki kemampuan untuk menghasilkan zat pengatur tumbuh berupa IAA alami. IAA merupakan golongan hormon auksin yang memiliki kemampuan dalam meningkatkan perpanjangan dan pembelahan sel tanaman, sehingga mampu meningkatkan pertumbuhan organ vegetatif tanaman jagung. Kemampuan inilah yang menjelaskan adanya pengaruh menguntungkan dari inokulasi Azotobacter sp. dalam meningkatkan jumlah daun dan luas daun, yang selanjutnya juga berpengaruh terhadap meningkatnya nilai indeks luas daun (Usharani et al., 2014 dan Kanchana et al., 2014).

Berdasarkan hasil pengamatan juga menunjukkan bahwa pemupukan urea secara mandiri memberikan pengaruh yang nyata terhadap peubah luas daun (Tabel 4) dan indeks luas daun (Tabel 6) pada saat tanaman jagung berumur 21 hst sampai dengan 81 hst, dan memberikan pengaruh nyata terhadap peubah jumlah daun (Tabel 2) pada saat tanaman jagung berumur 31 hst sampai dengan 81 hst.Secara umum, tanaman jagung yang diberi pupuk urea dengan taraf yang lebih tinggi memiliki jumlah daun, luas daun dan indeks luas daun yang lebih tinggi pula. Nitrogen merupakan penyusun klorofil, asam amino dan protein. Semakin tinggi ketersediaan unsur nitrogen dalam tanah, maka semakin cepat pula sintesis karbohidrat yang diubah menjadi protein dan protoplasma. Meningkatnya jumlah protein dalam tubuh tanaman akan meningkatkan kandungan nitrogen dalam jaringan tanaman yang selanjutnya digunakan untuk pertumbuhan vegetasi tanaman, di antaranya pertumbuhan bagian daun tanaman (Buana, Munandar dan Setyawan, 2013).

Tabel 7.Rata-Rata Bobot Segar dan Bobot Kering Total Tanaman Jagung Hasil Perlakuan Dosis Azotobacter sp. dan Pupuk Urea pada Umur 60 hst

\begin{tabular}{|c|c|c|}
\hline Perlakuan & $\begin{array}{c}\text { Bobot Segar } \\
\text { Total tanaman (g) }\end{array}$ & $\begin{array}{l}\text { Bobot Kering } \\
\text { Total Tanaman (g) }\end{array}$ \\
\hline \multicolumn{3}{|l|}{ Azotobacter sp. } \\
\hline $0 \mathrm{ml} \mathrm{l}^{-1}$ & $523,86 \mathrm{a}$ & $104,07 \mathrm{a}$ \\
\hline $10 \mathrm{ml} \mathrm{l}^{-1}$ & $520,17 \mathrm{a}$ & $108,41 \mathrm{ab}$ \\
\hline $20 \mathrm{ml} \mathrm{l}^{-1}$ & $611,62 \mathrm{~b}$ & $126,31 \mathrm{~b}$ \\
\hline BNT 5\% & 85,95 & 20,60 \\
\hline \multicolumn{3}{|l|}{ Urea } \\
\hline $0 \mathrm{~kg} \mathrm{ha}^{-1}$ & $326,84 \mathrm{a}$ & $55,53 \mathrm{a}$ \\
\hline $75 \mathrm{~kg} \mathrm{ha}^{-1}$ & $463,07 \mathrm{~b}$ & $89,00 \mathrm{~b}$ \\
\hline $150 \mathrm{~kg} \mathrm{ha}^{-1}$ & $626,68 \mathrm{c}$ & $126,02 \mathrm{c}$ \\
\hline $225 \mathrm{~kg} \mathrm{ha}^{-1}$ & $650,25 \mathrm{c}$ & $145,85 \mathrm{c}$ \\
\hline $300 \mathrm{~kg} \mathrm{ha}^{-1}$ & $692,59 \mathrm{c}$ & $148,25 \mathrm{c}$ \\
\hline BNT $5 \%$ & 110,96 & 26,60 \\
\hline $\mathrm{KK}(\%)$ & 20,83 & 24,39 \\
\hline
\end{tabular}

Keterangan: Bilangan yang didampingi oleh huruf yang sama pada kolom yang sama berarti tidak berbeda nyata berdasarkan uji BNT pada taraf 5\%; hst = hari setelah tanam; BNT = Beda Nyata Terkecil; KK = Koefisien Keragaman 
Berdasarkan hasil analisis ragam menunjukkan bahwa tidak terjadi interaksi yang nyata antara dosis Arotobacter sp. dan pupuk urea pada peubah bobot segar dan bobot kering total tanaman. Meskipun demikian, perlakuan dosis Azotobacter sp. dan pupuk urea masing-masing secara mandiri memberikan pengaruh yang nyata terhadap kedua peubah tersebut (Tabel 7).

Hasil pengamatan peubah bobot segar total tanaman menunjukkan bahwa pemberian Azotobacter sp. pada media tanam dengan dosis $20 \mathrm{ml} \mathrm{l}^{-1}$ mampu menghasilkan bobot segar total tanaman jagung tertinggi apabila dibandingkan dengan perlakuan lainnya (Tabel 7).Bobot segar total tanaman dipengaruhi oleh kandungan air pada sel-sel tanaman. Pemberian Azotobacter sp. dengan dosis $20 \mathrm{ml} \mathrm{l}^{-1}$ pada media tanam akan mampu menghasilkan hormon IAA alami. IAA merupakan zat pengatur tumbuh yang memiliki kemampuan dalam merangsang pertumbuhan akar melalui pertambahan panjang maupun luas permukaan akar tersebut, sehingga akar mampu mengikat air secara optimal, yang selanjutnya akan meningkatkan bobot segar total tanaman (Razie dan Anas, 2005).

Pada Tabel 7 di atas juga menunjukkan bahwa semakin tinggi taraf pemupukan urea akan meningkatkan bobot segar total tanaman yang dihasikan oleh tanaman jagung. Tanaman jagung yang diberi pupuk urea dengan taraf $150 \mathrm{~kg} \mathrm{ha}^{-1}$, $225 \mathrm{~kg} \mathrm{ha}{ }^{-1}$ dan $300 \mathrm{~kg} \mathrm{ha}^{-1}$ mampu menghasilkan bobot segar total tanaman yang lebih tinggi apabila dibandingkan dengan perlakuan lainnya. Hasil pengamatan bobot kering total tanaman (Tabel 7) menunjukkan bahwa semakin tinggi dosis inokulasi Azotobacter sp. maupun taraf pemupukan urea, maka diikuti dengan meningkatnya bobot kering total tanaman jagung. Inokulasi Azotobacter sp. dan pemupukan urea yang diberikan pada tanaman jagung bertujuan untuk meningkatkan ketersediaan nitrogen yang mampu dimanfaatkan oleh tanaman jagung.
Pada dasarnya, bobot kering tanaman mencerminkan laju fotosintesis tanaman. Unsur hara yang tersedia pada tanah, seperti halnya unsur nitrogen sangat berperan dalam proses metabolism pada tanaman untuk memproduksi bahan kering, yang bergantung pada laju fotosintesis. Dengan kata lain, fotosintesis akan menghasilkan asimilat yang terakumulasi menjadi bobot kering tanaman (Bustami et al., 2012).

\section{Hasil Tanaman}

Berdasarkan hasil analisis ragam menunjukkan bahwa tidak terjadi interaksi yang nyata antara dosis Azotobacter sp. dan pupuk urea pada komponen hasil tanaman jagung. Meskipun demikian, perlakuan dosis Azotobacter sp. dan pupuk urea masingmasing secara mandiri memberikan pengaruh yang nyata terhadap peubah jumlah biji per tanaman, bobot kering biji per tanaman, bobot kering biji per plot dan bobot kering biji per hektar (Tabel 8). Hasil pengamatan jumlah biji per tanaman menunjukkan bahwa semakin tinggi dosis inokulasi Azotobacter sp. maupun taraf pemupukan urea, maka diikuti dengan meningkatnya jumlah biji per tanaman yang mampu dihasilkan oleh tanaman jagung. Meskipun demikian, inokulasi Arotobacter sp.dengan dosis $10 \mathrm{ml} \mathrm{l}^{-1}$ dan $20 \mathrm{ml} \mathrm{l}^{-1}$ menghasilkan komponen hasil yang tidak berbeda nyata secara statistik. Begitu pula pemupukan urea dengan taraf150 kg ha-1, $225 \mathrm{~kg} \mathrm{ha}{ }^{-1}$ dan $300 \mathrm{~kg} \mathrm{ha}{ }^{-1}$, juga menghasilkan komponen hasil yang tidak berbeda nyata secara statistik.

Pemupukan urea maupun inokulasi Azotobacter sp., masing-masing keduanya akan memperbesar kemungkinan terjadinya peningkatan ketersediaan nitrogen yang dapat dimanfaatkan oleh tanaman jagung. Ketersediaan nitrogen yang cukup akan mampu meningkatkan jumlah biji per tanaman, yang selanjutnya akan meningkatkan bobot kering biji per tanaman. Hal ini sesuai dengan hasil pengamatan, di mana seiring dengan meningkatnya dosis 
N.W. Rachmadhani, D. Hariyono, M. Santosa/ Buana Sains Vol 18 No 1 : 1-10

inokulasi Azotobacter sp. maupun taraf pemupukan urea, maka mampu meningkatkan jumlah biji per tanaman dan bobot kering biji per tanaman. Hasil panen suatu tanaman dalam suatu luasan area tertentu sangat dipengaruhi oleh hasil panen

Tabel 8.Rata-Rata Jumlah Biji per Tanaman, Bobot Kering Biji per Tanaman, Bobot Kering Biji per Plot dan Bobot Kering Biji per Hektar Hasil Perlakuan Dosis Azotobacter sp. dan Pupuk Urea

\begin{tabular}{|c|c|c|c|c|}
\hline Perlakuan & $\begin{array}{c}\text { Jumlah Biji } \\
\text { per Tanaman } \\
\text { (Butir) }\end{array}$ & $\begin{array}{c}\text { Bobot } \\
\text { Kering Biji } \\
\text { per Tanaman } \\
\text { (g) }\end{array}$ & $\begin{array}{c}\text { Bobot } \\
\text { Kering Biji } \\
\text { per Plot } \\
\left(\mathrm{kg} \text { per } 1,2 \mathrm{~m}^{2}\right)\end{array}$ & $\begin{array}{c}\text { Bobot } \\
\text { Kering Biji } \\
\text { per Hektar } \\
\left(\mathrm{t} \mathrm{ha}^{-1}\right)\end{array}$ \\
\hline \multicolumn{5}{|l|}{ Azotobacter sp. } \\
\hline $0 \mathrm{ml} \mathrm{l}^{-1}$ & $316,43 \mathrm{a}$ & 140,63 a & $0,56 \mathrm{a}$ & $3,99 \mathrm{a}$ \\
\hline $10 \mathrm{ml} \mathrm{l}^{-1}$ & $459,13 \mathrm{~b}$ & $190,72 \mathrm{ab}$ & $0,76 \mathrm{ab}$ & $5,41 \mathrm{ab}$ \\
\hline $20 \mathrm{ml} \mathrm{l}^{-1}$ & $465,17 \mathrm{~b}$ & $194,15 \mathrm{~b}$ & $0,78 \mathrm{~b}$ & $5,50 \mathrm{~b}$ \\
\hline BNT $5 \%$ & 125,27 & 51,59 & 0,21 & 1,46 \\
\hline \multicolumn{5}{|l|}{ Urea } \\
\hline $0 \mathrm{~kg} \mathrm{ha}^{-1}$ & $203,61 \mathrm{a}$ & $87,12 \mathrm{a}$ & $0,35 \mathrm{a}$ & $2,47 \mathrm{a}$ \\
\hline $75 \mathrm{~kg} \mathrm{ha}^{-1}$ & $311,78 \mathrm{a}$ & $138,13 \mathrm{a}$ & $0,55 \mathrm{a}$ & $3,91 \mathrm{a}$ \\
\hline $150 \mathrm{~kg} \mathrm{ha}^{-1}$ & $502,44 \mathrm{~b}$ & $209,68 \mathrm{~b}$ & $0,84 \mathrm{~b}$ & $5,94 \mathrm{~b}$ \\
\hline $225 \mathrm{~kg} \mathrm{ha}^{-1}$ & $532,89 \mathrm{~b}$ & $220,50 \mathrm{~b}$ & $0,88 \mathrm{~b}$ & $6,25 \mathrm{~b}$ \\
\hline $300 \mathrm{~kg} \mathrm{ha}^{-1}$ & $517,17 \mathrm{~b}$ & $220,40 \mathrm{~b}$ & $0,88 \mathrm{~b}$ & $6,25 \mathrm{~b}$ \\
\hline BNT 5\% & 161,73 & 66,61 & 0,27 & 1,89 \\
\hline $\mathrm{KK}(\%)$ & 40,50 & 39,39 & 39,27 & 39,38 \\
\hline
\end{tabular}

Keterangan: Bilangan yang didampingi oleh huruf yang sama pada kolom yang sama berarti tidak berbeda nyata berdasarkan uji BNT pada taraf 5\%; BNT = Beda Nyata Terkecil; KK = Koefisien Keragaman

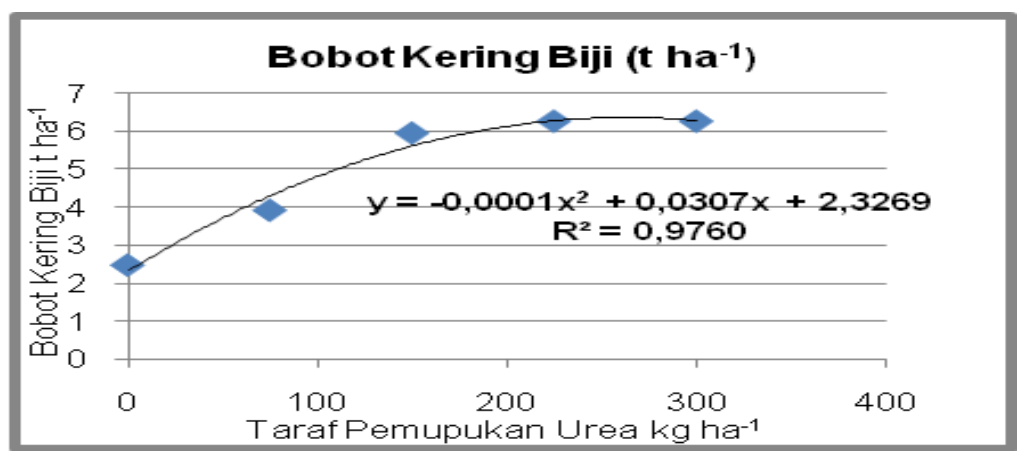

Gambar 1. Regresi Bobot Kering Biji yang Dihasilkan oleh Tanaman Jagung pada Berbagai Taraf Pemupukan Urea

Berdasarkan hasil analisis regresi pada Gambar 1 di bawah menunjukkan bahwa nilai bobot kering biji per hektar dipengaruhi oleh taraf pemupukan urea. Nilai koefisien determinasi $\left(\mathrm{R}^{2}\right)$ dari persamaan regresi di atas adalah 0,9760 , yang berarti bahwa hasil bobot kering biji per hektar dari tanaman jagung dipengaruhi oleh taraf pemupukan urea, di mana persentase pengaruhnya ialah sebesar $97,60 \%$. Berdasarkan hasil analisis regresi tersebut diperoleh persamaan regesi sebagai berikut : $\mathrm{y}=-0,0001 \mathrm{x}^{2}+0,0307 \mathrm{x}+2,3269$. Untuk mengetahui taraf optimum pemupukan urea dalam menghasilkan bobot kering biji per hektar, maka persamaan regresi tersebut 
harus diturunkan terlebih dahulu terhadap nilai $\mathrm{x}$, sehingga diperoleh persamaan baru hasil penurunan tersebut sebagai berikut: $0=$ $-0,0002 x+0,0307$. Dengan menyelesaikan persamaan baru tersebut, diketahui bahwa bobot kering biji per hektar yang dihasilkan oleh tanaman jagung akan mencapai nilai optimum apabila taraf pemupukan urea yang diberikan ialah sebesar 153,5 $\mathrm{kg} \mathrm{ha}{ }^{1}$.

\section{Kesimpulan}

1. Pemberian Azotobacter sp. dengan dosis $10 \mathrm{ml} \mathrm{l}^{-1}$ dan $20 \mathrm{ml} \mathrm{l}^{-1}$ pada pemupukan urea dengan taraf $150 \mathrm{~kg} \mathrm{ha}^{-1}$ mampu meningkatkan pertumbuhan tanaman jagung.

2. Inokulasi Azotobacter sp. pada media tanam, mampu meningkatkan hasil panen tanaman jagung. Peningkatan dosis inokulasi Azotobacter sp. lebih dari $10 \mathrm{ml} \mathrm{l}^{-1}$ tidak berpengaruh terhadap peningkatan produksi.

3. Produksi jagung mencapai nilai optimum apabila taraf pemupukan urea yang diberikan ialah sebesar 153,50 kg ha-1 .

\section{Daftar Pustaka}

Baral, B. R. and P. Adhikari. 2013. Effect of Azotobacter on Growth and Yield of Maize. J. Agric. 11 (2) : $141-147$

Buana, A. T., D. E. Munandar dan H. B. Setyawan. 2013. Pengaruh Dosis Pupuk Nitrogen dan Intensitas Sinar Matahari terhadap Pertumbuhan dan Hasil Jagung (Zea mays L.) Varietas Lokal Tuban. J. Ilmiah Pertanian. 1 (1) $: 1-10$

Bustami, Sufardi dan Bakhtiar. 2012. Serapan Hara dan Efisiensi Phosfat serta Pertumbuhan Padi Varietas Lokal. J. Manajemen Sumberdaya Lahan. 1 (2) : 159 - 170

Danapriatna, N. 2010. Biokimia Penambatan Nitrogen oleh Bakteri Non Simbiotik. J. Agribisnis \&
Pengembangan Wilayah. 1 (2) : 1 10

Hindersah, R., D. A. Sulaksana dan D. Herdiyantoro. 2014. Perubahan Kadar N Tersedia dan Populasi Azotobacter sp. di Rizosfer Sorgum (Sorghum bicolor L.) yang Ditanam pada Dua Ordo Tanah dengan Inokulasi Azotobacter sp. J. Agrologia. $3(1): 10-17$

Rao, N. S. S. 2010. Mikroorganisme Tanah dan Pertumbuhan Tanaman. UIPress. p. $100-124$

Razie, F. dan I. Anas. 2005. Potensi Azotobacter spp. (dari Lahan Pasang Surut Kalimantan Selatan) dalam Menghasilkan Indole Acetic Acid (IAA). J. Tanah dan Lingkungan 7 : $35-39$

Rosmarkam, A. dan N. W. Yuwono. 2002. Ilmu Kesuburan Tanah. Kanisius. Yogyakarta. p. $95-186$

Sitompul, S. M. dan B. Gurito. 1995. Analisis Pertumbuhan Tanaman. Gadjah Mada University Press. Yogyakarta. p. $152-217$

Syam'un, E., Kaimuddin dan A. Dachlan. 2012. Pertumbuhan Vegetatif dan Serapan Nitrogen Tanaman yang Diaplikasikan Pupuk Nitrogen Anorganik dan Mikroba Penambat Nitrogen Non-Simbiotik. J. Agrivigor. 11 (2) : 251 - 261

Usharani, G., D. Sujitha and S. Sivasakthi. 2014. Effect of Azotobacter sp. for the Improvement of Growth and Yield of Pearl Millet (Cumbu) (Pennisetum Glaucum L.). Int. J. of Adv. Multi. Res. 1 (1) : 102 - 106

Widiyawati, I., Sugiyanta, A. Junaedi dan R. Widyastuti. 2014. Peran Bakteri Penambat Nitrogen untuk Mengurangi Dosis Pupuk Nirtogen Anorganik pada Padi Sawah. J. Agron. Indonesia 42 (2) : $96-102$ 